Personalidade Acadêmica Homenageada:

Augustus B. Cochran III (Agnes Scott College)

\title{
A INTOLERÂNCIA RELIGIOSA NO SÉCULO DA DESINFORMAÇÃO: QUESTÕES ACERCA DO ISLAMISMO NO BRASIL
}

\author{
RELIGIOUS INTOLERANCE IN THE CENTURY OF \\ DISINFORMATION: ISSUES ABOUT ISLAMISM IN BRAZIL
}

JULIA MARIA GOMES ALVES

Graduanda em Direito, na modalidade integral, pela Escola Superior Dom Helder Câmara. Belo Horizonte/MG. Email: juliamgalves9@gmail.com.

CAIO AUGUSTO SOUZA LARA Mestre e Doutor em Direito pela Faculdade de Direito da Universidade Federal de Minas Gerais - UFMG. Professor da Escola Superior Dom Helder Câmara. Pesquisador Associado ao Programa RECAJ-UFMG - Acesso à Justiça e Solução de Conflitos. Secretário de Comunicação do Conselho Nacional de Pesquisa e Pósgraduação em Direito - CONPEDI. Belo Horizonte-MG. E-mail: caiolarabh@yahoo.com.br.

\section{RESUMO}

O problema objeto da investigação científica proposta são os fatores responsáveis pela disseminação do preconceito contra a religião islã no Brasil no século XXI e seus reflexos no universo jurídico. Uma pesquisa feita a partir de dados do Ministério dos Direitos Humanos, constatou que de janeiro de 2015 até o primeiro semestre do ano de 2016, foram registradas no Brasil uma denúncia a cada 15 horas contra casos de intolerância religiosa. Dentre os casos registrados pode-se analisar desde agressões verbais à invasão de templos e destruição de imagens 


\section{Personalidade Acadêmica Homenageada:}

\section{Augustus B. Cochran III (Agnes Scott College)}

sacras. A principal alavanca para a escolha desse tema é a indignação contra os ataques à liberdade de expressão, liberdade de culto e à dignidade dos indivíduos seguidores da religião islâmica, uma vez que, muitos deles ao deixar sua terra de origem e procurar se instalar em outros territórios e em outras sociedades pelos mais diversos motivos, tornam-se vítimas de difamação, agressão física ou psicológica, repressão e até mesmo de exclusão social. A busca desses povos por uma provável condição de vida mais favorável acaba se tornando um desafio quando não conseguem, por exemplo, ser admitidos em algum emprego simplesmente por praticarem um culto diferente daquele que predomina naquele território, ou por usarem vestimentas distintas daquelas que as pessoas daquela sociedade usam. A partir das reflexões preliminares sobre o tema, é possível afirmar inicialmente que o Brasil é um país predominantemente Cristão e conservador quando se diz respeito à religião. A predominância de uma cultura judaico-cristã atrelada ao baixo índice de desenvolvimento educacional do país resulta num quadro de desinformação por parte população quanto às religiões orientais liga-se à pergunta fundamental da presente pesquisa: o que leva à intolerância religiosa com os praticantes do islamismo? A associação da religião islâmica com o terrorismo faz com que grande parte dos indivíduos repudiem aqueles que são adeptos a ela. $O$ objetivo geral da pesquisa é analisar a incompatibilidade histórica entre o islamismo e o cristianismo e a partir daí constatar quais motivos geram esse preconceito contra os povos islâmicos no Brasil. É importante destacar o papel da política quando se fala de liberdade religiosa. No cenário atual, de um mundo polarizado, muitos governos de países democráticos estão cometendo o equívoco de adotar para si um religião base. Quando uma figura de Estado, de grande influência para o povo, afirma em seu discurso político uma determinada religião ou fundamenta suas propostas nela, ele acaba legitimando inconscientemente ou não a possibilidade de repressão às demais religiões. A tentativa de reger um país democrático a partir de fundamentos de uma determinada religião é, no mínimo absurdo, além de ferir os direitos fundamentais da inviolabilidade a liberdade de consciência e crença, garantidas na Constituição da República Federativa do Brasil. A pesquisa que se propõe pertence à vertente metodológica jurídico-sociológica. No tocante ao tipo de 
Personalidade Acadêmica Homenageada:

Augustus B. Cochran III (Agnes Scott College)

investigação, foi escolhido, na classificação de Witker (1985) e Gustin (2010), o tipo histórico-jurídico. O raciocínio desenvolvido na pesquisa será predominantemente dialético. Como conclusão parcial da presente pesquisa, tem-se que a ignorância e a arrogância ocidental são fatores relevantes para a disseminação da intolerância religiosa Islã. O Brasil é a prova de que onde não há Estado, a igreja exerce um papel fundamental. Neste caso, o Cristianismo é a matriz religiosa dominante e que desempenha grande influência sobre a população, é tido como um norte único e ditador de regras no país, tudo isso gera a não aceitação e o não respeito às demais religiões, especialmente o islamismo e as de matriz africana.

PALAVRA-CHAVE: Islamismo; preconceito; intolerância; violência.

\section{REFERÊNCIAS}

BRASIL. Constituição da República Federativa do Brasil de 1988. Brasilia, DF, 1988.

BOFF, Leonardo; Fundamentalismo, Terrorismo, Religião e Paz: desafio para o século XXI. Editora Vozes: Petrópolis, RJ, 2009.

GUSTIN, Miracy Barbosa de Sousa; DIAS, Maria Tereza Fonseca. (Re)pensando a pesquisa jurídica: teoria e prática. 3ª . ed. Belo Horizonte: Del Rey, 2010.

HUNTINGTON, Samuel P.; Choque de Civilizações. Simon \& Schuster; Nova York, 1996.

PORTUGAL. Constituição da República Portuguesa. Lisboa, 1976.

POSSA, Ana Lethea da Cunha. A Eficácia da Declaração Universal dos Direitos Humanos. Revista Jurídica - UNICURITIBA v. 20, n. 4, 2007.

RESK, Felipe; TOMAZELA, José Maria; COTRIM, Jonathas. Brasil Registra uma denúncia de intolerância religiosa a cada 15 horas. Estadão. 12 nov. 2017. Disponível em: https://brasil.estadao.com.br/noticias/geral,brasil-registra-umadenuncia-de-intolerancia-religiosa-a-cada-15-horas,70002081286. Acesso em: 26 maio de 2019. 
Personalidade Acadêmica Homenageada:

Augustus B. Cochran III (Agnes Scott College)

WITKER, Jorge. Como elaborar una tesis en derecho: pautas metodológicas y técnicas para el estudiante o investigador del derecho. Madrid: Civitas, 1985. 